[Agr. Biol. Chem., Vol. 31, No. 2, p. 142 149, 1967]

\title{
Studies on the Fluorescence of Saké
}

\section{Part II. Factors Affecting the Formation of Harman in Saké}

\author{
By Sumio Takase and Hideya Murakami \\ Research Institute of Brewing, Tax Administration Agency \\ Received August 8, 1966
}

\begin{abstract}
The pathway of the formation of a blue fluorescent substance, harman, and the factors affecting its formation in Saké were studied. Harman content in Saké was increased by exposing to UV ray, sun light, visible ray and IR ray or by keeping at high temperature. It was confirmed that harman in Saké was formed by the condensation of tryptophane with acetaldehyde or with serine, especially with acetaldehyde. The formation of harman from tryptophane and acetaldehyde was stimulated at $\mathrm{pH} 2 \sim 4$ and also by ethanol. This reaction was one of interesting photochemical changes of components in seasoning of Saké.
\end{abstract}

In the previous paper, ${ }^{11}$ it was reported that blue fluorescence of Saké kept under direct sun light increased remarkably and it was due to the formation of a basic fluorescent substance, harman, in Saké. In this paper, the pathway of the formation of harman and the factors affecting its formation in Saké were studied.

\section{METHODS}

1. Exposing to various kinds of rays. The samples $(50 \sim 100 \mathrm{ml})$ in Fernbach-flasks or petridishes were exposed to various kinds of rays under $20 \mathrm{~cm}$ from the lamps. The lamps used were as follows.

Infra red ray: Toshiba IR lamp $500 \mathrm{~W}$

Ultra violet ray: National germination lamp $15 \mathrm{~W}$

Visible ray: Toshiba photo-reflector lamp $500 \mathrm{~W}$

2. Measurement of fluorescence energy and paper chromatography. To the samples exposed to various kinds of rays or kept at varied temperatures water was added to original volume. A $20 \mathrm{ml}$ aliquot of this solution and $5 \mathrm{ml}$ of $2 \mathrm{~N}$ sodium hydroxide solution were mixed, then $75 \mathrm{ml}$ of water was added. The solution was shaken with ether

1) S. Takase and H. Murakami, This Journal, 30, 869 (1966).
$(100 \mathrm{ml})$, and the ethereal solution was shaken with $1 \mathrm{~N} \mathrm{HCl}(100 \mathrm{ml})$. Then the relative value of fluorescence energy of this acidic solution (hereafter to be abbreviated as R. E.) was measured at excitation wave length of $370 \mathrm{~m} \mu$ and emission wave length of $430 \mathrm{~m} \mu$ by the method as mentioned in the previous paper. Five gram of sodium hydroxide was then added and the solution was shaken with $100 \mathrm{ml}$ of ether. The ethereal solution was dehydrated and concentrated, the residue was dissolved in ethanol and chromatographed by the method as mentioned in the previous paper.

\section{EXPERIMENTAL}

1. Extraction and quantitative determination of harman

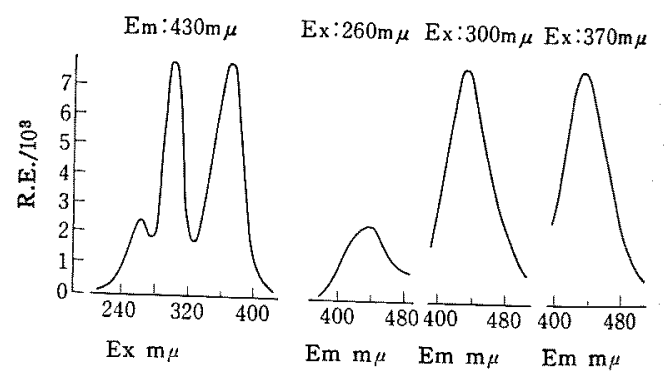

FIG. 1. Fluorescence Spectrum of Harman.

1 p.p.m. in $1 \mathrm{~N} \mathrm{HCl}$ Ex: Excitation wave lengt Em: Emission wave length 
Fluorescence spectrum of harman as shown in Fig. 1 has two peaks (Ex $300 \mathrm{~m} \mu \sim \operatorname{Em~} 430 \mathrm{~m} \mu$ and Ex 370 $\mathrm{m} \mu \sim \operatorname{Em} 430 \mathrm{~m} \mu$ ), but the hight of these peaks were similar. In this paper, at the outset, main component in $\mathrm{HCl}$ extract of each sample was ascertained to be harman by paper chromatography, fluorescence spectrum and UV absorption spectrum. As the fluorescence energy corresponding with the concentration of harman, R. E. at Ex $370 \mathrm{~m} \mu \sim \operatorname{Em} 430$

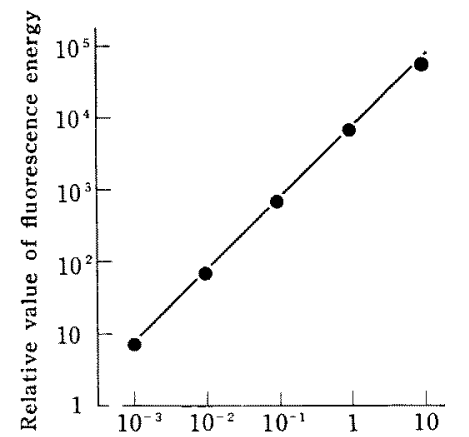

Concentration of harman (p.p.m.) in $1 \mathrm{~N} \mathrm{HCl}$

FIG. 2. Relation between Concentration of Harman and R.E.

Fig. 2 shows that concentration of harman is given with the following expression.

Concentration of harman (p.p.m.) $=\frac{\text { R.E. }}{7000}$ $\mathrm{m} \mu$ was measured.

In $1 \mathrm{~N} \mathrm{HCl}$ solution, the relation between logarithms of concentration of both harman and R. E. was found to be rectilineal on wide range from 0.001 to 10 p.p.m. as shown in Fig. 2. And the recovery of harman in $\mathrm{HCl}$ extract was satisfactory. Therefore in this paper, the amount of harman was calculated from the R. E.

\section{Factors stimulating the formation of harman} in Saké

R. E. of HCl extracts of Sakés exposed to UV ray (at $20^{\circ} \mathrm{C}$ ), visible ray (cooling with water at $20^{\circ} \mathrm{C}$ ) and $\mathrm{IR}$ ray (at $90^{\circ} \mathrm{C}$ ) or those kept at varied temperatures were measured, then these fractions were chromatographed. The results were shown in Table I. R. E. of extract was increased by exposing to UV ray, visible ray or IR ray. And always only one blue fluorescent spot showing the same $R_{F}$ value as that of harman was observed on the paper chromatogram. The white crystal obtained from Saké treated by the method as mentioned in the previous paper showed the identical UV absorption spectrum with that of harman. And the fluorescence spectrum of each sample was also identical with that of harman.

Concerning the effect of temperature, Saké kept at $20^{\circ} \mathrm{C}$ and $30^{\circ} \mathrm{C}$ did not increase in R. E., but those kept at $43^{\circ} \mathrm{C}$ and $60^{\circ} \mathrm{C}$ increased in R. E. Chromatogram of this fraction showed the blue fluorescent spot with the same $R_{F}$ as that of harman.

TABLE I. EFFECT OF VARIOUS KINDS OF RAYS AND TEMPERATURE ON THE FORMATION OF HARMAN IN SAKÉ

Treatment

Before treatment

In dark place at R. T.

Exposing to IR ray

Exposing to IR ray

Exposing to UV ray

Exposing to visible ray

In dark place at $20^{\circ} \mathrm{C}$

In dark place at $30^{\circ} \mathrm{C}$

In dark place at $43^{\circ} \mathrm{C}$

In dark place at $60^{\circ} \mathrm{C}$

Harman
R. E. $\quad \begin{aligned} & \text { Harman } \\ & \mu \mathrm{g} / 50 \mathrm{ml}\end{aligned}$

$\begin{array}{lr}\text { for } 24 \text { hrs. } & 50 \\ \text { for } 6 \text { hrs. } & 626 \\ \text { for } 24 \text { hrs. } & 1906 \\ \text { for } 24 \text { hrs. } & 1250 \\ \text { for } 4 \text { hrs. } & 226 \\ \text { for } 70 \text { hrs. } & 50 \\ \text { for } 70 \text { hrs. } & 50 \\ \text { for } 70 \text { hrs. } & 66 \\ \text { for } 70 \text { hrs. } & 306\end{array}$

1.7

22.2

67.6

44.3

8.0

1.7

1.7

2.3

10.8
Fluorescent spot on the paper

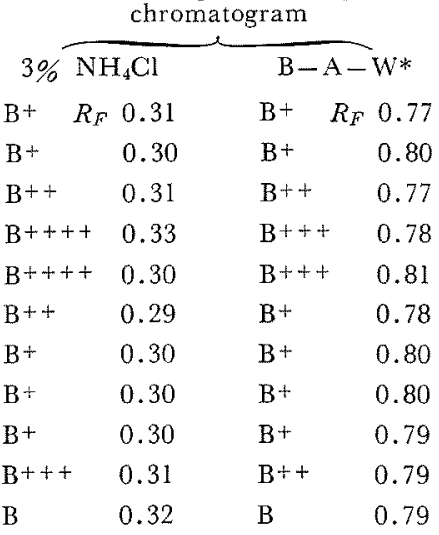

B: blue fluorescence + : intensity of fuorescence

* butanol-acetic acid-water $(4: 1: 4)$ 
TABLE II. EFFECT OF VARIOUS Kinds OF RAYS AND TEMPERATURE ON THE Formation of HaRman by Condensation of TRY with ACETaldehyde

\begin{tabular}{|c|c|c|c|c|c|c|c|c|c|c|c|}
\hline \multirow[b]{2}{*}{ Treatment } & \multirow[b]{2}{*}{ R. E. } & \multirow{2}{*}{$\begin{array}{c}\text { Harman } \\
\text { formed } \\
\mu \mathrm{g} / 50 \mathrm{ml}\end{array}$} & \multicolumn{8}{|c|}{ Fluorescent spots on the paper chromatogram } & \\
\hline & & & \multicolumn{3}{|c|}{$5 \% \mathrm{NH}_{4} \mathrm{OH}$} & \multicolumn{4}{|c|}{$3 \% \mathrm{NH}_{4} \mathrm{Cl}$} & \multicolumn{2}{|c|}{$\begin{array}{l}3 \% \text { acetic } \\
\text { acid }\end{array}$} \\
\hline Before treatment & 14 & - & Not fo & found & & Not fo & und & & & Not $\mathrm{fo}$ & ound \\
\hline At $10^{\circ} \mathrm{C}$ for $240 \mathrm{hrs}$. & 480 & 16 & $\mathrm{~B}^{+}$ & $0.11^{*}$ & & $\mathrm{~B}^{+}$ & 0.33 & & & $\mathrm{~B}^{+}$ & 0.45 \\
\hline At $30^{\circ} \mathrm{C}$ for $120 \mathrm{hrs}$ & 3552 & 125 & $\mathrm{~B}^{++}$ & 0.11 & & $\mathrm{Y}^{+}$ & 0.12 & $\mathrm{~B}^{++}$ & 0.33 & $\mathrm{~B}^{++}$ & 0.45 \\
\hline At $45^{\circ} \mathrm{C}$ for 96 hrs. & 6528 & 231 & $\mathrm{~B}^{+++}$ & 0.11 & & $\mathrm{Y}^{+}$ & 0.11 & $\mathrm{~B}^{+++}$ & 0.33 & $\mathrm{~B}^{+++}$ & 0.45 \\
\hline At $60^{\circ} \mathrm{C}$ for $48 \mathrm{hrs}$. & 8448 & 299 & $\mathrm{~B}^{+++}$ & 0.11 & & $\left\{\begin{array}{l}\mathbf{L B}^{+} \\
\mathrm{B}^{++++}\end{array}\right.$ & $\begin{array}{l}0.03 \\
0.33\end{array}$ & $\mathrm{Y}^{+}$ & 0.11 & $\mathrm{~B}^{+++}$ & 0.45 \\
\hline $\begin{array}{l}\text { Exposing to UV ray } \\
\text { for } 48 \text { hrs. }\end{array}$ & 23850 & 846 & $\left\{\begin{array}{l}\mathrm{B}++++ \\
\mathrm{B} \pm\end{array}\right.$ & $\begin{array}{l}0.11 \\
0.26\end{array}$ & $Y \pm 0.21$ & $\left\{\begin{array}{l}\mathrm{Y}^{++} \\
\mathrm{B}^{+++++}\end{array}\right.$ & $\begin{array}{l}0.04 \\
0.33\end{array}$ & $\begin{array}{l}\mathrm{B}^{+} \\
\mathrm{Y}^{+}\end{array}$ & $\begin{array}{l}0.17 \\
0.48\end{array}$ & $\mathrm{~B}^{++++}$ & 0.45 \\
\hline $\begin{array}{l}\text { Exposing to IR ray } \\
\text { for } 48 \mathrm{hrs} .\end{array}$ & 81000 & 2875 & $\mathrm{~B}^{++++}$ & 0.11 & $\mathrm{~B} \pm 0.26$ & $\left\{\begin{array}{l}\mathrm{LB}^{+++} \\
\mathrm{B}^{++++}\end{array}\right.$ & $\begin{array}{l}0.04 \\
0.33\end{array}$ & $\mathrm{~B}^{+}$ & 0.50 & $\mathrm{~B}^{++++}$ & 0.45 \\
\hline $\begin{array}{l}\text { Exposing to sun light } \\
\text { for } 77 \text { hrs. }\end{array}$ & 48600 & 1725 & $\mathrm{~B}^{++++}$ & 0.11 & $B \pm 0.25$ & $\left\{\begin{array}{l}\mathrm{LB}^{++} \\
\mathrm{B}^{++++}\end{array}\right.$ & $\begin{array}{l}0.04 \\
0.33\end{array}$ & $\mathrm{Y}^{+}$ & 0.11 & $\mathrm{~B}^{++++}$ & 0.45 \\
\hline & & & $B$ & 0.11 & & B & 0.33 & & & B & 0.45 \\
\hline
\end{tabular}

Color of fuorescence; B: blue, Y: yellow, LB: light blue + ; intensity of fluorescence $* R_{F}$ value

\section{Pathway of the formation of harman}

Harvey et al. ${ }^{2}$ prepared harman by condensation of tryptophane (Try) with acetaldehyde. Tschesche et al. ${ }^{3)}$ reported that by boiling Try with serine (Ser) in $25 \% \mathrm{H}_{2} \mathrm{SO}_{4}$ harman was formed. From these informations, it was presumed that harman in Saké was formed by condensation of Try with acetaldehyde or with Ser.

3-1. Formation of harman by condensation of Try with acetaldehyde. Twenty $\theta_{0}$ ethanol solution ( $\mathrm{pH} 4.2$ ) containing 400 p.p.m. of Try and 4000 p.p.m. of acetaldehyde was prepared. Aliquots of $50 \mathrm{ml}$ of this solution were kept in dark places at varied temperatures or exposed to UV ray, IR ray and direct sun light $\left(a t 40^{\circ} \mathrm{C}\right.$ ), then the R. E. were measured. Table II showed the results. For the samples kept at $30^{\circ} \mathrm{C}, 45^{\circ} \mathrm{C}$ and $60^{\circ} \mathrm{C}$, the R. E. increased and at the same time the blue fluorescent spot on the paper appeared strongly. The same fact was observed for the samples exposed to UV ray, IR ray and direct sun light. By exposing to IR ray or direct sun light, the temperature of sample remarkably rose. And as shown in Fig. 3, the white crystal obtained from the sample was found to show

2) D. G. Harvey and W. Robson, J. Chem. Soc., $1938,97$. 3) R. Tschesche, H. Jenssen and P. N. Rangachari,
Chem. Ber., 91, 1732 (1958). the identical UV absorption spectrum with that of harman.

3-2. Formation of harman by condensation Try with Ser. Aqueous solution ( $\mathrm{pH} 4.0$ ) containing 400 p.p.m. of Try and 210 p.p.m. of Ser was prepared. Aliquots of $50 \mathrm{ml}$ of this solution were kept in dark place at $20^{\circ} \mathrm{C}$, at $70^{\circ} \mathrm{C}$ and exposed IR ray, then the R. E. were measured. The results were shown

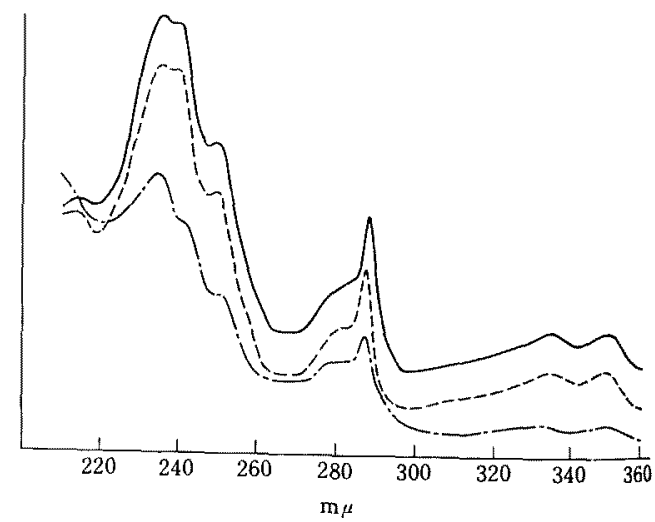

FIG. 3. UV Absorption Spectra of Harman.

- Authentic harman

- - - Substance formed by condensation Try with acetaldehyde

-.-. Substance formed by condensation Try with Ser 
Table III. The Formation of HaRman by the Condensation OF TRY WITH SER

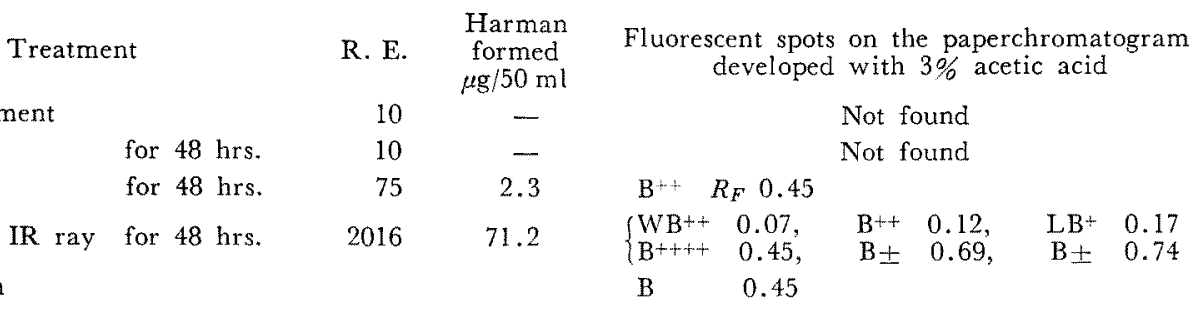

Before treatment

At $20^{\circ} \mathrm{C}$

At $70^{\circ} \mathrm{C}$

Exposing to IR ray for $48 \mathrm{hrs}$.

Harman
Color of fluorescence; B: blue, WB: whitish blue, LB: light blue

+ ; Intensity of fluorescence

in Table III. The developed paper was cut off around the areas showing the same $R_{F}$ as that of harman. Fig. 3 indicated that white sublimatic substance from these piece of paper showed the same UV absorption spectrum as did harman.

3-3. Pathway of formation of harman in Saké. Yamada ${ }^{4}$ reported that acetaldehyde content in young Saké was 50 p.p.m of average. From the data shown by Sasaki,5) acetaldehyde content in Saké was calculated to be 16 p.p.m. On the other hand, Tamura et al.6) reported that Try content in Saké was 29 p.p.m. and Takaoka et al.7) reported that Ser content in Saké was $250 \sim 300$ p.p.m. In molar concentrations, Try content was $0.14 \mathrm{mM}$, Ser content $2.8 \mathrm{~mm}$ and acetaldehyde content $0.36 \mathrm{mM}$ (calculated from Sasaki's data), therefore Saké contained more Ser than acetaldehyde. From the ratio of molar concentration, it

Table IV. Comparison of ACETAldehyde aND SER IN EFFECT ON THE FORMATION OF HARMAN

$\begin{array}{lrc} & \text { R. E. } & \begin{array}{c}\text { Harman formed } \\ \mu \mathrm{g} / 50 \mathrm{ml}\end{array} \\ \text { Try+ Acetaldehyde } & 352 & 10.5 \\ \text { Try+Ser } & 104 & 1.7 \\ \text { Try } & 56 & - \\ \text { Try: } 15 \mathrm{mg} / 50 \mathrm{ml} & & \\ \text { Acetaldehyde: } 8 \mathrm{mg} / 50 \mathrm{ml} & \\ \text { Ser: } 150 \mathrm{mg} / 50 \mathrm{ml} & \end{array}$

4) M. Yamada, Rep. Res. Inst. Brew. Japan, 93, 273 (1925).

5) K. Sasaki, J. Agr. Chem. Soc. Japan, 38, 309 (1964).

6) G. Tamura, T. Tsunoda, J. Kirimura and $S$. Miyazawa, J. Agr. Chem. Soc. Japan, 26, 480 (1952).

7) H. Takaoka, K. Nishiwaki, K. Honma, H. Hatano, S. Takano and H. Yamada, Annual Meeting of the Society of Fermentation Technology, Japan (1964). seemed that the condensation of Try with Ser occurred more easily than with acetaldehyde. Therefore the possible pathway was investigated.

The solution ( $\mathrm{pH} 4.0$ ) containing Try and acetaldehyde or Try and Ser in tenfold concentration in Saké was prepared. After exposure to IR ray for 24 hrs., the R. E. was measured. Table IV showed the results. The acetaldehyde content was less than $1 / 18$ of Ser content (as molar concentration, less than 1/7) but the amount of harman formed from Try and acetaldehyde was more than that from Try and Ser, therefore the affinity between Try and acetaldehyde was considered to be stronger than that between Try and Ser.

3-4. Relation between the ratio of acetaldehyde to Try and the amount of harman formed. The solution containing $2 \mathrm{mM}$ concentration of Try, $0.2 \mathrm{mM} \sim 60 \mathrm{mM}$ concentration of acetaldehyde and 20.6 of $\mathrm{M} / 10$ lactate buffer solution ( $\mathrm{pH} 4.0$ ) were prepared. Aliquots of $50 \mathrm{ml}$ of these solutions in flasks were kept in light place at $20^{\circ} \mathrm{C}$ (aside the northerly window of laboratory) and in the dark place at $30^{\circ} \mathrm{C}$, then the R. E. were measured. From the R. E., the amount of harman formed was calculated. Fig. 4 showed the results.

There was rectilineal relationship between logarithms of both the amount of acetaldehyde and that of harman formed. In Fig. 4 the gradients of straight lines on the diagram under various conditions showed the similar values and the intercepts were differed with different conditions. Therefore, when the amount of acetaldehyde under the settled concentration of Try was varied, the amount of harman formed under this condition and after settled time was given with the following expression.

$$
H=C \times A^{a}
$$




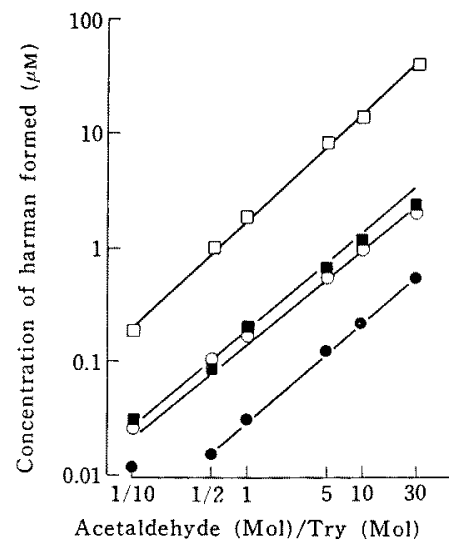

FIG. 4. Relation between the Ratio of Acetaldehyde to Try and the Concentration of Harman Formed.

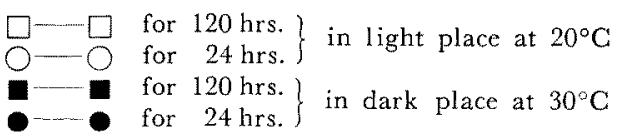

in this expression;

$H=$ the amount of harman formed

$A=$ the amount of acetaldehyde coexisting with Try

$C=$ a constant varied with conditions

$a=$ a constant not varied with conditions

4. Factors affecting the formation of harman.

4-1. Effect of $\mathbf{p H}$ and temperature. Aliquots of $50 \mathrm{ml}$ of aqueous solution containing 400 p.p.m. of Try and 4000 p.p.m. of acetaldehyde were adjusted $\mathrm{pH}$ to $1 \sim 10$. After the solution had been kept at $70^{\circ} \mathrm{C}$ for $48 \mathrm{hrs}$, the amounts of harman formed were measured. On the other hand, the flasks filled with the same solution adjusted $\mathrm{pH}$ to 4.0 were kept

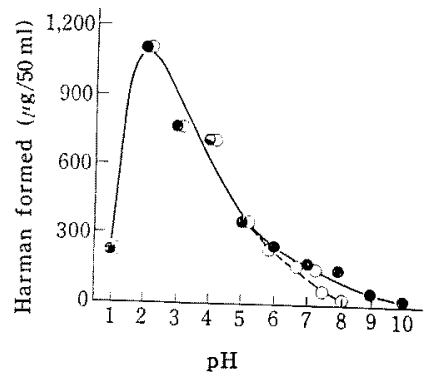

FIG. 5. Effect of $\mathrm{pH}$ on the Formation of Harman.

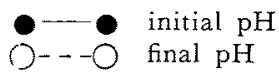

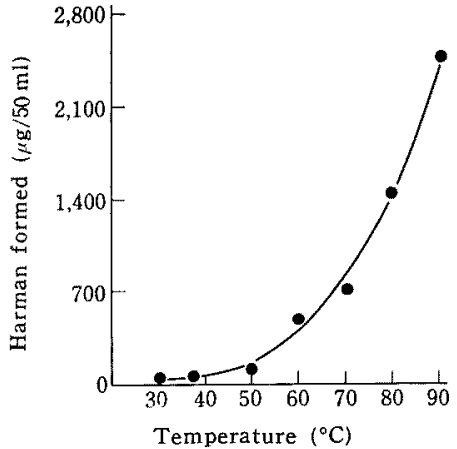

FIG. 6. Effect of Temperature on the Formation of Harman.

in dark places at varied temperature $30^{\circ} \sim 90^{\circ} \mathrm{C}$ for 48 hrs. The results were shown in Fig. 5 and 6 . It was found that the formation of harman was stimulated at acidic side especially at $\mathrm{pH} 2 \sim 4$ and at high temperature.

4-2. Effect of shaking and deoxygenation. Aliquots of $50 \mathrm{ml}$ of the solution having the composition shown in Table $\mathrm{V}$ were shaken in the dark place at $30^{\circ} \mathrm{C}$ for $120 \mathrm{hrs}$. On the other hand, 100 $\mathrm{ml}$ flasks without stoppers filled with aliquots of $50 \mathrm{ml}$ of the same solution were put in the desiccator deoxygenated using alkaline pyrogallol. The desccator was kept at $30^{\circ} \mathrm{C}$ for $120 \mathrm{hrs}$. As shown in Table VI, effect of shaking was not found but the formation of harman was diminished by deoxygenation.

4-3. Effect of bottle's color and ethanol. Aliquots of $100 \mathrm{ml}$ of the solution (shown in Table V) were put in flasks. These flasks were kept in dark place at $5^{\circ} \mathrm{C}$, at $20^{\circ} \mathrm{C}$, at $30^{\circ} \mathrm{C}$ and aside the northerly

TABle V. The Composition of the SOLuTJon TESTED

Try

$400 \mathrm{mg}$

Acetaldehyde $4000 \mathrm{mg}$

M/l0 lactate buffer solution $(\mathrm{pH} 4.0) \quad 200 \mathrm{ml}$

Total volume $1000 \mathrm{ml}$

TABLE VI. EFFECT OF SHAKING AND DEOXYGENATION ON THE FORMATION OF HARMAN

Treatment

Stationary kecping

Harman formed $\mu \mathrm{g} / 50 \mathrm{ml}$

23.2

23.2

4.2 $\%$ 100 100 18 


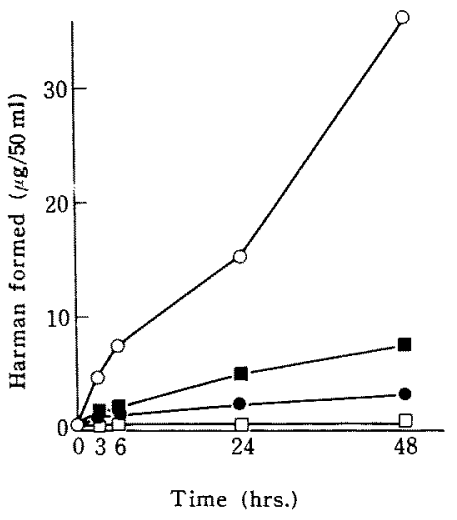

FIG. 7. Effect of Dispersed Day Light on the Formation of Harman.

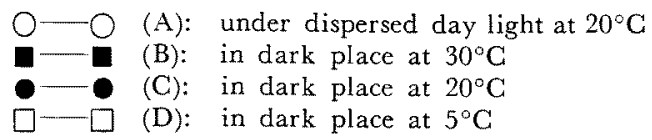

window of laboratory (described as in light place at $20^{\circ} \mathrm{C}$ ), then the amounts of harman formed were measured. The results were shown in Fig. 7, in which $B-D$ showed the effect of temperature and A-C showed that of exposing to dispersed day light. The fact that exposing to dispersed day light showed the remarkable stimulating effect was interesting.

It was already reported that exposing to day light affected browning and deterioration of Saké and the degree of deterioration varied according to storage bottle's color. ${ }^{8-11}$ i Therefore effects of bottle's color and ethanol were studied. The solution (shown in Table $V$ ) and the same solution containing $20 \%$ of ethanol were put in transparent, blue and pale brown bottles. These bottles were kept aside the northerly window of laboratory. The results were shown in Fig. 8. The effect of ethanol was apparent and bottle's colors stimulated the formation of harman in the order: pale brown $<$ blue $<$ transparent, Four kinds of colored bottle's glass showed the transmittance $(T) \%$ to UV ray as follows ${ }^{8}$; deep brown $=0$, pale brown $=18$, blue $=58 \sim 64$, transparent $=88 \sim 90$, and the order of $T \%$ coincided with that of stimu-

8) H. Katada, J. Soc. Brew. Japan, 54, 348 (1959). 9) H. Akiyama, T. Furukawa and M. Nagasawa, ibid., 55, 780 (1960).

10) J. Yamamoto, ibid., 57, 889 (1962).

11) M. Takahashi, ibid., 58, 1129 (1963).

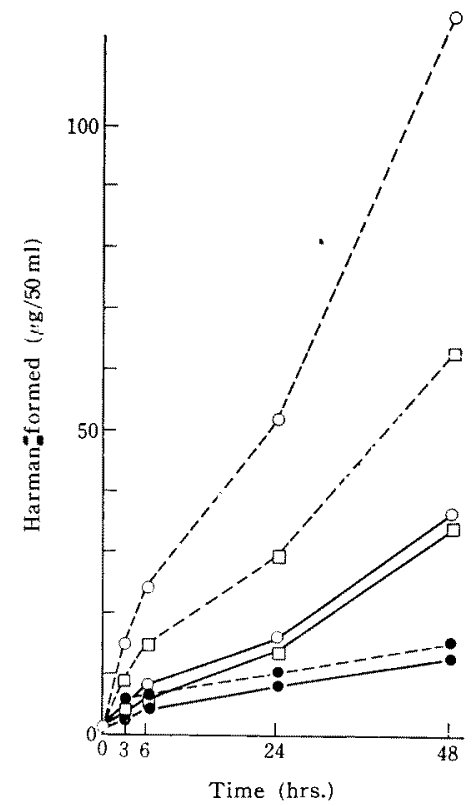

FIG. 8. Effect of Bottle's Color on the Formation of Harman.

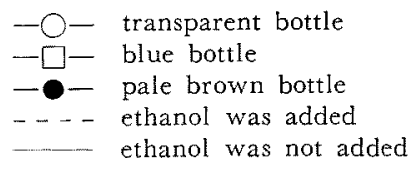

lating effect on the formation of harman. These results indicated that stimulating effect of exposing to day light was due to the ray ranging from visible short wave to UV area.

4-4. Effect of ethanol content. Aliquots of $50 \mathrm{ml}$ of the solution (shown in Table V) containing $0 \sim 60 \%$ of ethanol were kept in light place or in dark place, then the amounts of harman formed were measured. Fig. 9 showed the results. Stimulating effects of ethanol were found under both conditions, in light or in dark place, and the optimum concentrations were $30 \sim 40 \%$.

Next, stimulating effect of ethanol on condensation of Try with Ser was studied. Aliquots of $50 \mathrm{ml}$ of the solution containing $2 \mathrm{mM}$ concentration of Try and Ser respectively, $20 \%$ of $\mathrm{M} / 10$ lactate buffer solution ( $\mathrm{pH} 4.0$ ) and $0 \sim 60 \%$ of ethanol were kept in light place at $20^{\circ} \mathrm{C}$ for $120 \mathrm{hrs}$. At the same time the solution containing $2 \mathrm{mM}$ concentration of acetal- 


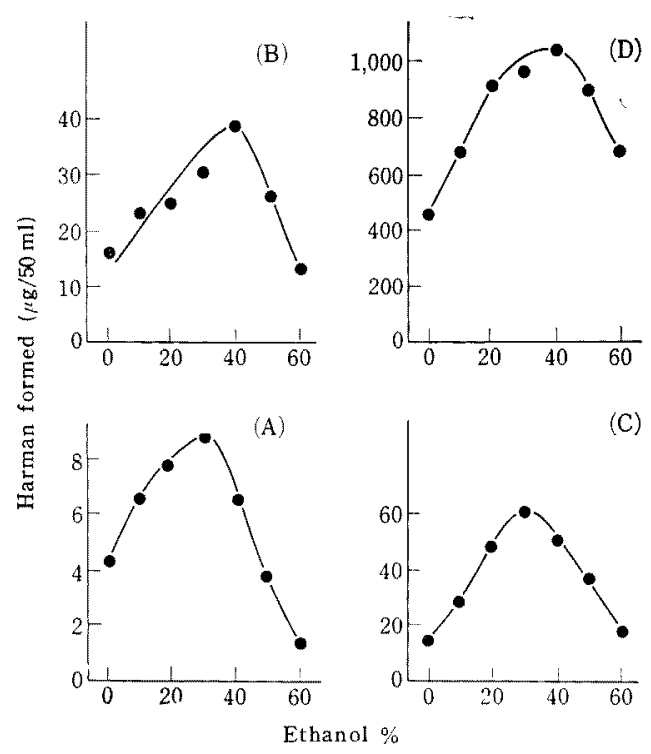

FIG. 9. Effect of Ethanol on the Formation of Harman.

(A) for 24 hrs. in dark place at $30^{\circ} \mathrm{C}$

$\left.\begin{array}{l}\text { (C) for } 24 \mathrm{hrs} \text {. } \\ \text { (D) for } 120 \mathrm{hrs}\end{array}\right\}$ in light place at $20^{\circ} \mathrm{C}$

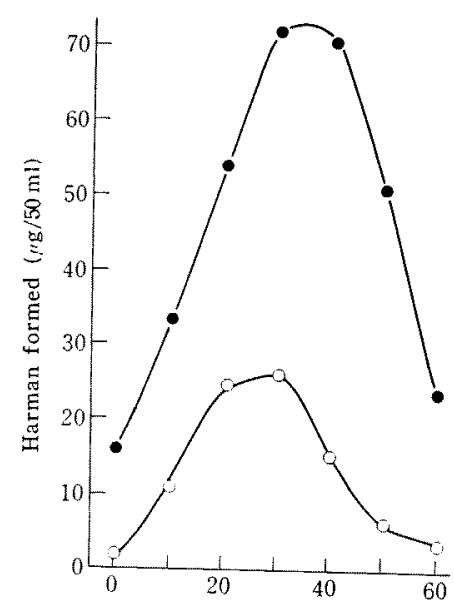

Ethanol \%

FIG. 10. Effect of Ethanol on the Formation of Harman from Try and Ser.

- Try + acetaldehyde

$\bigcirc-O$ Try+Ser dehyde instead of Ser was similarly treated. As shown in Fig. 10, ethanol also stimulated the condensation of Try with Ser and its optimum concentration was $30 \%$.

4-5. Effect of various kinds of enzymatic agents. To the solution (shown in Table V), commercial enzymatic agent $\mathrm{A}, \mathrm{B}$ or extracts from rice koji or barley malt was added. After these solutions had been kept in dark place at $30^{\circ} \mathrm{C}$ for $120 \mathrm{hrs}$, the amounts of harman formed were measured. The results were shown in Table VII. Effect of agent $A$ was hardly found. That the effect of denaturated agent $B$ was small but addition of native agent $B$ increased remarkably the formation of harman seemed to indicate that agent $B$ itself, as an enzyme, was effective. Agent B has been known to contain acid protease and cellulase, but which component is effective must further be investigated.

It was found that extracts from koji and malt diminished the formation of harman but denaturated extracts also showed negative effect. These results indicated that this negative effect was due to some components extracted from koji or malt.

TABLE VII. EFFECT OF VARIOUS KINDS OF ENZY* MATIC Agents on the Formation of HaRMaN Enzymatic agents $\begin{gathered}\text { Harman formed } \\ \mu \mathrm{g} / 50 \mathrm{ml}\end{gathered}$

Koji extract*1 $\begin{cases}3.4 & 17\end{cases}$

Koji extract (denatrd.*2) $\begin{cases}3.9 * 4 & 20 \\ 5.0 & 26\end{cases}$

Malt extract $\begin{cases}3.3 & 17\end{cases}$

$\begin{cases}3.3 & 12 \\ 2.4 & 0.6\end{cases}$

Malt extract (denatrd.) $\quad \begin{cases}8.6 & 44 \\ 8.9 & 45\end{cases}$

Agent $A^{* 3} \quad \begin{cases}21.2 & 109\end{cases}$

Agent A (denatrd.) $\begin{cases}22.7 & 117 \\ 20.4 & 105\end{cases}$

Agent B $\quad\{386.0 \quad 1981$

$\{386.0 \quad 1981$

Agent B (denatrd.) $\quad \begin{cases}24.3 & 125\end{cases}$

$\begin{array}{lll}\text { Not added } & 19.4 & 100\end{array}$

*1 With $300 \mathrm{ml}$ of dist. water, $110 \mathrm{~g}$ of koji or milled malt was extracted for $3 \mathrm{hrs}$, and 30 $\mathrm{ml}$ of the filtrate was contained in $50 \mathrm{ml}$ of the solution.

*2 Enzyme was denaturated by keeping at $120^{\circ} \mathrm{C}$ for $20 \mathrm{~min}$.

*3 The amount of agent was $0.1 \%$ in the solution.

*4 Each test was done in two flasks respectively. 
TABLE VIII. EFFECT OF MINERAL IONS ON THE FORMATION OF HARMAN

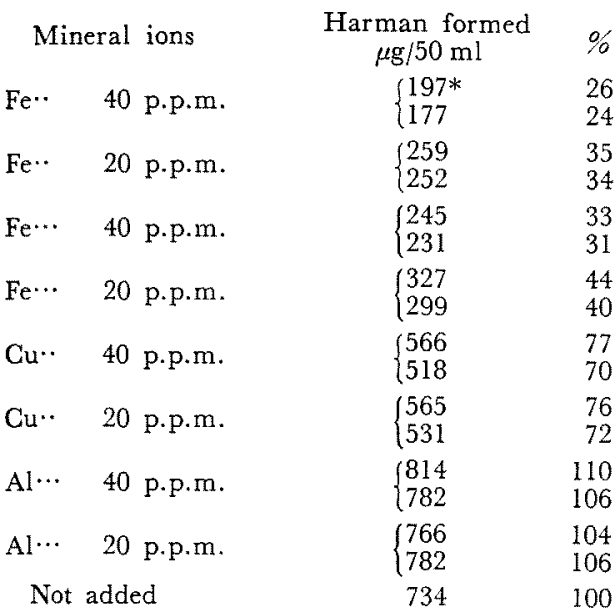

* Each test was done in two flasks respectively.

4-6. Effect of mineral ions. Aliquots of $50 \mathrm{ml}$ of the solution (shown in Table V) containing $40 \%$ of M/10 lactate buffer solution ( $\mathrm{pH} 4.0$ ), 40 or 20 p.p.m. of $\mathrm{Fe}, \mathrm{Cu}$ and $\mathrm{AI}$ ions were kept in light place at $20^{\circ} \mathrm{C}$ for $85 \mathrm{hrs}$. The results were shown in Table VIII. Addition of $20 \sim 40$ p.p.m. of Fe and $\mathrm{Cu}$ diminished the formation of harman, but that of Al did not affect the formation.

\section{DISCUSSION}

It was proved that harman in Saké was formed by condensation of Try with acetaldehyde or with Ser, especially with acetal- dehyde. The optimum $\mathrm{pH}$ of this condensation was $2 \sim 4$, and at alkaline side this reaction hardly occurred. The $\mathrm{pH}$ of Sake commonly been $4.0 \sim 4.4$, was most suitable one for formation of harman. The amount of harman formed at $30 \sim 40^{\circ} \mathrm{C}$ was more than that at $20^{\circ} \mathrm{C}$. Considering that seasoning of Saké was accelerated especially at $30 \sim 40^{\circ} \mathrm{C}$, we supposed that the formation of harman was one of interesting changes of components in seasoning of Saké.

Furthermore, the formation of harman was stimulated by exposing to various kinds of rays. This effect was able to be divided into two factors, the one was temperature rise by irradiation and the other was ray itself ranging from visible short wave to UV area. Especially that the formation of harman was remarkably stimulated by dispersed day light and that the amount of harman formed by exposing to $\mathrm{UV}$ ray at $20^{\circ} \mathrm{C}$ was more than that formed by keeping at $60^{\circ} \mathrm{C}$ suggested that this reaction was one of photochemical reactions in Saké.

Acknowledgements. The authors wish to express their thanks to Dr. Meiji Suzuki, the director of Research Institute of Brewing, for his willing help throughout the experiment; to the Japan Saké Brewers Central Association, Tokyo, which afforded facilities for making spectrofluorophotometric analysis. 